\title{
EFFECT OF A PRE-PLANTING TREATMENT OF SEED TUBERS WITH LOW-FREQUENCY PULSE ELECTRIC FIELD ON THE GROWTH OF POTATO PLANTS OF DIFFERENT VARIETIES
}

\section{N.V. STATSYUK ${ }^{1}$, K. THAKUR ${ }^{2}$, T.I. SMETANINA ${ }^{1}$, M.A. KUZNETSOVA ${ }^{1}$}

\author{
${ }^{1}$ All-Russian Research Institute of Phytopathology, Federal Agency of Scientific Organizations, 5, ul. Institute, \\ Bol'shie Vyazemy, Odintsovskii Region, Moscow Province, 143050 Russia, e-mail nataafg@gmail.com, kuz- \\ netsova@vniif.ru; \\ ${ }^{2}$ Tuberosum Technologies Inc., Broderick, SK, S0H 0L0 Canada, e-mail khyalct@yahoo.co.in \\ Received March 4, 2016
}

\section{Abstract}

In spite of high biological potential demonstrated in field trials, many potato cultivars did not show a full productivity at a large-scale production that can be caused by both external (cultivation conditions) and internal (quality and adaptive potential of seed material) factors. To date, a number of seed-stimulating technologies based on the use of the laser, ultrasound, cold plasma, magnetic and electromagnetic fields have been developed. A pre-planting treatment of seeds with low-frequency pulse electric field (LF-PEF) was proved to have a positive effect on the seed qualities and productivity of some agricultural crops including lettuce, parsley, red beet, and carrot. However, the mechanisms of this effect still remain unclear. In this study we assessed the response of 13 different potato varieties to the LF-PEF treatment on several morphometric traits. The study was carried out at three geographical points: Tuberosum Technologies LLC (Saskachewan, Canada, 2009, 11 varieties of different reproductions used for the baby potato production), the field of All-Russian Research Institute of Phytopathology (ARRIP, Moscow Province, 2011; variety Saturna), and Ozery LLC (Moscow Province, 2012; variety Lady Clair). For each variety, $20 \mathrm{~kg}$ (Tuberosum Technologies), $200 \mathrm{~kg}$ (ARRIP), and 2 tons (Ozery) of seed potato were treated 3-5 days prior the planting using an experimental LF-PEF generator developed by the Intelpro LLC (Russia). Generated electric field was characterized by a broadband frequency range and had the following parameters: carrier frequency $16 \pm 10 \mathrm{kHz}$, repetition rate of the modulating pulse pattern $200 \mathrm{~Hz}$, generated field intensity $20 \mathrm{kV} / \mathrm{m}$. According to the earlier optimized mode, the seed potato was exposed to LF-PEF for $24 \mathrm{~h}$. Protective treatments with fungicides were the same for both treated and untreated plants used as control. Plant height, number of stems per plant, number of leaves per stem, fresh weight of above-ground parts, and the number and total weight of tubers per plant were measured at flowering; each variant (control or treatment) included 10 plants in four repetitions. For the majority of the studied varieties, the LF-PEF treatment did not significantly influence on plant height, number of leaves per stem, and fresh weight of above-ground parts of plants. At the same time, the number of stems per plant and the number and weight of tubers per a plant increased; the revealed changes were reliable and significant for the majority of varieties (80-95\%). The variety-averaged increase in the number of stems and the number and weight of tubers per plant made $27.0,28.3$ и $31.1 \%$, respectively, as compared to the control. The obtained data agree with the results of our earlier large-scale trials of the LF-PEF technology arranged in different regions of Russia.

Keywords: potato, low-frequency pulse electric field, morphometric traits, pre-planting treatment, crop capacity

Potato (Solanum tuberosum L.) is one of the most important crops in Russia. Despite a significant reduction of cultivated areas in the last 15 years, Russia ranks third in the world in potato production, being inferior to China and India only [1]. However, compared to European and North American countries, potato productivity remains relatively low in the conditions of Russia which creates certain difficulties for import substitution in agricultural products. Therefore, the problem of increasing potato yields is still valid

Many potato cultivars have a high biological productivity potential of 6575 and even 100-120 t/ha [2, 3], but the yields are much lower in most Russian farms averaging 10-20 t/ha [4]. This discrepancy is due to both external (cultivation conditions) and internal (quality and adaptive potential of seed material) 
factors. Therefore, potato productivity may be increased not only by competent agricultural practices and the use of high reproductive improved seeds but also through the use of technologies that could increase the adaptive capacity of cultivars against biotic and abiotic stresses. These technologies include pre-planting seed treatment with chemical or biological agents and physical fields which have a stimulating effect on plant germination and development [5-8]. It is worth noting that the use of physical fields belongs to environmentally-friendly methods of stimulation, which can be considered as an additional advantage in the conditions of growing environmental pollution by pesticides and other chemicals [9].

Plants sensitivity to physical factors such as light, sound, magnetic, electrical and electromagnetic fields is due to the fact that they have been and are the natural components of the environment throughout the history of the existence and evolution of plants. To date, a number of seed-stimulating technologies based on the use of the laser, ultrasound, cold plasma, magnetic and electromagnetic fields have been developed [10-14].

Thus, the positive effects of pre-sowing seed treatment with electrostatic field [15], cold plasma [16, 17], alternating magnetic field [18], and electromagnetic field (EMF) of industrial frequency [19-22] on germination, development and productivity of plants has been demonstrated in vegetables, cereals and ornamental crops. Pre-planting treatment of seeds with low-frequency pulse electric field (LF-PEF) belonging to the same group of technologies has been proved to have a positive effect on the seed qualities and productivity of some agricultural crops including lettuce, parsley, red beet, and carrot [23-26]. Tuber treatment with LF-PEF resulted in accelerated germination (7-9 days earlier), increased germination by the average of $29.5 \%$, and earlier budding and flowering $[27,28]$. In addition, the positive effects of LF-PEF treatment on potato yield have been confirmed by many years of trials [29]. However, the mechanisms of this effect still remain unclear and require the studies of physiological, biochemical, and biophysical processes in the treated plants.

In this study, we the first assessed the effects of pre-planting LF-PEF treatment on several morphometric traits in a wide range of potato varieties and reproductions grown in various geographic areas (Canada, two districts of the Moscow region). Preliminary results have been published partially [30].

Our objective was to study the response of various potato (Solanum tuberosum L.) cultivars and reproductions to the pre-planting LF-PEF treatment of tubers.

Technique. The study eas performed in Tuberosum Technologies (Canada, 2009, 11 varieties of different reproductions used for Baby potato production), Ozery CJSC (Ozery district, Moscow region, 2011, variety Saturna), and in the experimental field of All-Russian Research Institute of Phytopathology (ARRIP, Moscow region, 2012, variety Lady Clair). For each variety, $20 \mathrm{~kg}$ (Tuberosum Technologies), $200 \mathrm{~kg}$ (ARRIP), and 2 tons (Ozery) of seed potato were treated. Seed potato was treated 3-5 days prior to planting using an experimental LF-PEF generator SEF (Intelpro LLC, Russia). Generated electric field was characterized by a broadband frequency range which made it close to natural electrical and electromagnetic fields. Characteristics of generated electric field: carrier frequency of $16 \pm 10 \mathrm{kHz}$, repetition rate of the modulating pulse pattern of $200 \mathrm{~Hz}$, generated field intensity of $20 \mathrm{kV} / \mathrm{m}$. According to the earlier optimized mode, potato was exposed to LF-PEF for $24 \mathrm{~h}$ [27]. The treatment of experimental variants was performed at the distance of at least 10-15 meters from the control ones to avoid the impact on the latter.

Experiments were performed using routine fungicide treatments that were the same for both LF-PEF treated and untreated plants. In Canada, 5- 
fold Bravo SC fungicide treatments (Syngenta, Switzerland, 2.5 1/ha) were performed. The following fungicides were used in ARRIP: Shirlan (0.4 1/ha) single treatment, Ridomil Gold MC (2.5 1/ha) - two treatments, Revus $(0.6 \mathrm{l} / \mathrm{ha})+$ Score $(0.4 \mathrm{l} / \mathrm{ha})$ - single treatment; Shirlan $(0.4 \mathrm{l} / \mathrm{ha})$ - final single treatment (all preparations manufactured by Syngenta, Switzerland). In Ozery CJSC, the regime included the following preparations: Shirlan $(0.4 \mathrm{l} / \mathrm{ha})-$ single treatment, Infinito (Bayer Crop Science, Germany; 1.4 1/ha) - two treatments, Sectin Fenomen (Bayer Crop Science, Germany; $1.25 \mathrm{~kg} / \mathrm{ha}$ ) - two treatments, Shirlan $(0.4 \mathrm{l} / \mathrm{ha})$ - single treatment. The first treatment was conducted after the joining of above-ground parts in the rows. The interval between treatments was 10-15 days.

1. Potato (Solanum tuberosum L.) cultivars and reproductions used to assess the effects of LF-PEF exposure on plant morphometric parameters

\begin{tabular}{|c|c|}
\hline Name & Reproduction \\
\hline \multirow{2}{*}{\multicolumn{2}{|c|}{$\begin{array}{l}\text { Tuberosum Technologies, } \\
\text { Outlook, Saskachewan (Canada) 2009. }\end{array}$}} \\
\hline & la), 2009: \\
\hline \multicolumn{2}{|c|}{ Baby Boomer Pre-Elite, Elite 1} \\
\hline Belana & Elite 3 \\
\hline Blue Lady & Elite 3 \\
\hline Blushing Belle & Elite 1 , Elite 2 \\
\hline Everest & Pre-Elite \\
\hline F-98-44-2 & Pre-Elite \\
\hline HO 2000 & Pre-Elite, Elite 1, Elite 4 \\
\hline Piccolo & Elite 1 , Elite 2 \\
\hline Russet Burbank & Pre-Elite, Elite 1 \\
\hline Saphire & Elite 2, Elite 3 \\
\hline Umatilla Russet & Elite 1 \\
\hline \multicolumn{2}{|l|}{ Ozery CJSC, } \\
\hline \multicolumn{2}{|c|}{ Ozery Region, Moscow Province, 2011: } \\
\hline Saturna & First \\
\hline \multicolumn{2}{|c|}{ All-Russian Research Institute of Phytopathology, } \\
\hline \multicolumn{2}{|c|}{ Odintsovo Region, Moscow Province, 2012: } \\
\hline \multicolumn{2}{|c|}{$\begin{array}{l}\text { Note. LF-PEF - low-frequency pulse electric field used for } \\
\text { pre-planting treatment of seed tubers. Reproductions are speci- } \\
\text { fied according to classifications adopted in the countries of } \\
\text { experiments. }\end{array}$} \\
\hline
\end{tabular}

Morphometric observations were performed at flowering; every variant (control and LF-PEF treatment) included 10 plants in 4-fold replicates. Plant height, number of stems per plant, number of leaves per stem, fresh weight of above-ground parts, and the number and total weight of tubers were measured.

Statistical processing was performed according to B.A. Dospekhov method [31] at $95 \%$ confidence level using Microsoft Excel 2003 and Statistica 6.0 application packages and univariate ANOVA analysis (v. 1.02).

Results. Table 1 shows potato cultivars tested and their reproductions (by the countries).

Six morphometric parameters studied could be divid-

ed into two groups according to cultivar responses to pre-planting LF-PEF treatment. In group I (plant height, number of leaves per stem, fresh weight of above-ground parts), the changes averaged over total cultivars studied were minimal (for the first two parameters, especially) being insignificant in cases (Fig., Table 2). In group II (number of stems per plant, number and weight of tubers per plant) all the changes were positive and significant for most cultivars and reproductions (see Fig., Table 2). There was no correlation between the reproduction number and the level of changes in the parameters studied in different reproductions of cultivars.

These data suggest the presence of significant positive effect of preplanting LF-PEF treatment on the number of stems per plant, and the number and weight of tubers harvested from one plant for the majority of cultivars and reproductions studied (80-95\%). At the same time, the absolute values of growth rates for various cultivars and reproductions differed.

Changes in plant height, number of leaves per stem and fresh weight of above-ground parts of plants was not always positive for most cultivars and reproductions and was insignificant and variety-dependent in most cases.

Increased numbers and weights of tubers per plant (indicators directly related to potato yield) observed in all cultivars confirms the positive effect of pre-planting LF-PEF treatment on productivity demonstrated earlier in produc- 
tion technology trials at potato-growing farms (1996-2009). In these experiments, the yield increase ranged from 8.7 to $58.0 \%$ in different cultivars and in different regions of Russia, averaging $28.2 \%$ [29].
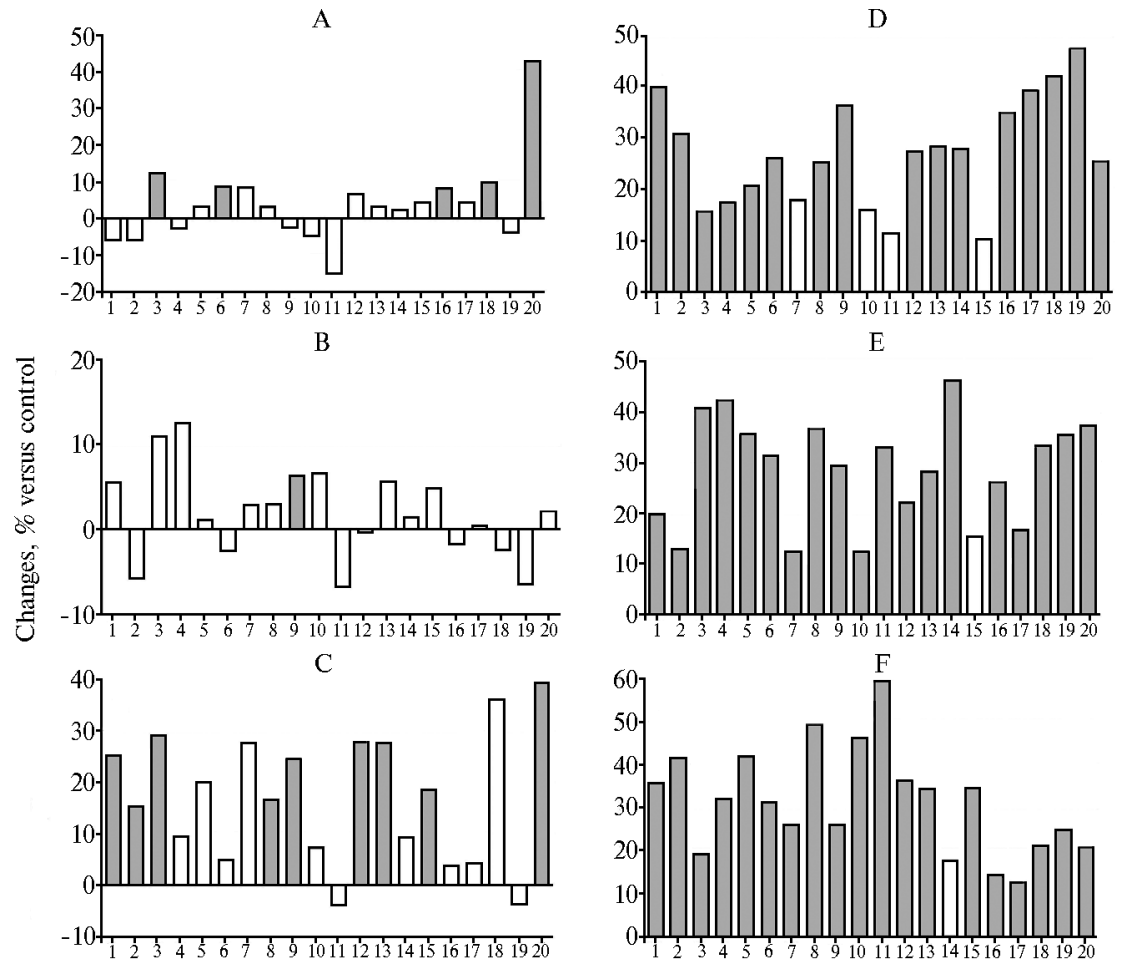

Cultivars, reproduction

Average changes in plant height (A), number of leaves per stem (B), fresh weight of above-ground parts $(C)$, number of stems (D), number (E) and weight of tubers (F) in potato (Solanum tuberosum L.) cultivars and reproductions with pre-planting treatment of seed tubers with low-frequency pulse electric field: 1 - Boomer PE, 2 - Boomer E1, 3 - Blue Lady, 4 - Belana, 5 - Blushing Belle E1, 6 - Blushing Belle E2, 7 - Everest, 8 - F-98-44-2, 9 - HO 2000 PE, 10 - HO 2000 E1, 11 - HO 2000 E4, 12 - Piccolo E1, 13 - Piccolo E2, 14 - Russet Burbank PE, 15 - Russet Burbank E1, 16 - Saphire E2, 17 - Saphire E3, 18 - Umatilla Russet (Canada); 19 - Saturna, 20 Lady Claire (Moscow Province). Variants with significant $\left(\operatorname{LSD}_{0.95}\right)$ differences from control are shown in dark color.

2. Morphometric parameters of potato (Solanum tuberosum L.) with pre-planting low-frequency pulse electric field treatment of seed tubers (averaged results for cultivars and reproductions, 2009-2012, Canada and Moscow Province)

\begin{tabular}{l|c|c|c|c|c}
\hline \multirow{2}{*}{\multicolumn{1}{c}{ Parameter }} & \multicolumn{3}{|c|}{ Changes, \% versus control } & \multicolumn{2}{c}{$\begin{array}{c}\text { Proportions of cultivars (reproductions) } \\
\text { with LSD } 0.95 \text { changes, \% }\end{array}$} \\
\cline { 2 - 6 } & min & max & average & significant & insignificant \\
\hline Number of leaves per stem & -6.74 & 12.50 & 1.88 & 5 & 95 \\
Plant height & -15.01 & 42.90 & 3.86 & 25 & 75 \\
Fresh weight of above-ground & -3.97 & 39.22 & 16.91 & 45 & 55 \\
parts & 10.30 & 47.40 & 27.00 & 80 & 20 \\
Number of stems & 12.30 & 46.04 & 28.28 & 95 & 5 \\
Number of tubers & 12.48 & 59.28 & 31.14 & 95 & 5 \\
Weight of tubers &
\end{tabular}

Our results are consistent with the data obtained by other authors. Thus, pre-planting treatment with electrostatic field $(400 \mathrm{kV} / \mathrm{m})$, demonstrated no significant effects on plant height and a distinct cultivar-dependent response (from insignificant differences to $10 \%$ ) in the four potato cultivars, as in our case [32]. Under the exposure to alternating electric field $(50 \mathrm{~Hz})$ [33] and alternating magnetic field (40 and $80 \mathrm{mT}$ ) [34], a significant increase in the 
number of stems of 62.2 and $24.3 \%$, respectively, was found. Treatment of potato tubers with electrostatic field $(400 \mathrm{kV} / \mathrm{m}, 12 \mathrm{~min})$ increased the mean number of tubers $(35.7 \%)$ and yield $(11.0 \%)$ significantly in cultivar Sante; these changes were less pronounced and insignificant in cultivar Desiree [32], which is likely due to the cultivar-dependent response or non-optimal parameters of the field used. Treatment of tubers with corona discharge field $(50 \mathrm{kV}, 5 \mathrm{~s})$ resulted in an increase in potato yields by $3.8 \mathrm{t} / \mathrm{ha}$ as well [35]. Cold plasma treatment provided medium increases in yield by $26.4 \%$ [36]. Microwave flooding increased potato productivity by $10-17 \%$ [37].

Thus, we demonstrated that pre-planting low-frequency pulse electric field (LF-PEF) treatment did not significantly influence the following morphometric parameters: potato plant height, number of leaves per stem, and fresh weight of above-ground parts of plants. At the same time, we identified a significant positive response to LF-PEF treatment for the number of stems per plant and the number and weight of tubers per plant in all cultivars (reproductions) studied. The variety-averaged increase in these parameters made 27.0, 28.3, and $31.1 \%$ versus control (for the last two ones, it is consistent with the results of earlier production tests). Increased number and weight of tubers per plant determines the positive effect LF-PEF treatment on potato yield.

\section{REFEREN CES}

1. FAOSTAT data. Available: http://faostat3.fao.org/browse/Q/QC/E [Accessed 28 March 2016].

2. To rikov V.E., B o g o m a z O.A. Vestnik Bryanskoi gosudarstvennoi sel'skokhozyaistvennoi akademii, 2008, 4: 53-59 (in Russ.).

3. Gale ev R.R. Vestnik Altaiskogo gosudarstvennogo agrarnogo universiteta, 2011, 4(78): 5-9 (in Russ.).

4. I va ny u k V.G., B a n a d y e v S.A., Z hu ro ms ki i G.K. Zashchita kartofelya ot boleznei, vreditelei $i$ sornyakov [Potato plant protection against diseases, pests and weeds]. Minsk, 2005 (in Russ.).

5. Prusakova L.D., Ma levannaya N.N., B elopukhov S.L., Vakulenko V.V. Agrokhimiya, 2005, 11: 76-86 (in Russ.).

6. Spirov G.M., Valueva Yu.V., M erkulova V.G., Medvedeva L.N., Luk'yan o v N.B., Z a its e v A.S. Uspekhi sovremennogo estestvoznaniya, 2008, 6: 30-38 (in Russ.).

7. R e e d M.L.E., G li c k B.R. Applications of free living plant growth-promoting rhizobacteria. Antonie Van Leeuwenhoek, 2004, 86: 1-25 (doi: 10.1023/B:ANTO.0000024903.10757.6e).

8. Marinković B., Grujić M., Marinković D., Crnobarac J., Marinković J., J a ći mović G., Mircov D.V. Use of biophysical methods to improve yields and quality of agricultural products. Journal of Agricultural Sciences, 2008, 53(3): 235-242.

9. A ladjadjiy an A. Physical factors for plant growth stimulation improve food quality. In: Food production - approaches, challenges and tasks. A. Aladjadjiyan (ed.). Rijeka, InTech, 2012: 145-168 (doi: 10.5772/32039).

10. Goussous S.J., Samarah N.H., Alqudah A.M., Othman M.O. Enhancing seed germination of four crop species using an ultrasonic technique. Exp. Agr., 2010, 46(2): 231-242 (doi: 10.1017/S0014479709991062).

11. Hernandez A.C., Dominguez P.A., Cruz O.A., Ivanov R., Carballo C.A., Z e p e d a B.R. Laser in agriculture. Int. Agrophys., 2010, 24(4): 407-422.

12. Bilalis D.J., Katsenios N., Efthimiadou A., Karkanis A., Khah E.M., Mits is T. Magnetic field pre-sowing treatment as an organic friendly technique to promote plant growth and chemical elements accumulation in early stages of cotton. Australian Journal of Crop Sciences, 2013, 7(1): 46-50.

13. M affe i M.E. Magnetic field effects on plant growth, development, and evolution. Front. Plant Sci., 2014, 5: 445 (doi: 10.3389/fpls.2014.00445).

14. M a slobrod S.N., Ko rle ty a n u L.B., G a n y A.I. Elektronnaya obrabotka materialov, 2010, 5: 93-105 (in Russ.).

15. Yang L., S h e n H. Effect of electrostatic field on seed germination and seedling growth of Sorbus pohuashanesis. Journal of Forestry Research, 2011, 22(1): 27-34 (doi: 10.1007/s11676-011-0120-9).

16. Mi hai A.L., D obri n D., M a gure a nu M., P op a M.E. Positive effects of non-thermal plasma treatment on radish seeds. Romanian Reports in Physics, 2014, 66(4): 1110-1117.

17. J i a ng J., H e X., Li L., Li J., S h a o H., X u Q., Y e R., D ong Y. Effect of cold plasma treatment on seed germination and growth of wheat. Plasma Science and Technology, 2014, 16(1): 54-58 (doi: 10.1088/1009-0630/16/1/12). 
18. R a dhakrish nan R., K u mari B.D.R. Pulsed magnetic field: a contemporary approach offers to enhance plant growth and yield of soybean. Plant Physiol. Bioch., 2012, 51: 139-144 (doi: 10.1016/j.plaphy.2011.10.017).

19. J e d li čk a J., P a u le n O., A i le r Š. Influence of magnetic field on germination, growth and production of tomato. Potravinarstvo, 2014, 8(1): 150-154 (doi: 10.5219/349).

20. Y a n D.-L., G u o Y.-Q., Z a i X.-M., W a n S.-W., Q i n P. Effects of electromagnetic fields exposure on rapid micropropagation of beach plum (Prunus maritima). Ecol. Eng., 2009, 35: 597-601 (doi: 10.1016/j.ecoleng.2008.04.017).

21. Mahmood M., B e e O.B., Mahmud T., Subramania m S. The growth and biochemical responses on in vitro cultures of Oncidium taka orchid to electromagnetic field. Australian Journal of Crop Science, 2011, 5(12): 1577-1587.

22. Molamofrad F., Lotfi M., Khazaei J., Tavakkol-Afshari R., Shaiega$\mathrm{ni}-\mathrm{Ak} \mathrm{m}$ a 1 A. The effect of electric field on seed germination and growth parameters of onion seeds (Allium cepa). Advanced Crop Science, 2013, 3(4): 291-298.

23. Ku rbakov E.L. Effektivnost' novykh elementov tekhnologii vyrashchivaniya salata v Nechernozemnoi zone Rossii. Avtoreferat kandidatskoi dissertatsii [Effectiveness of novel cultivation elements on salad in the Russian Non-chernozem zone. PhD Thesis]. Moscow, 2007 (in Russ.).

24. Kurbakova O.V. Povyshenie posevnykh kachestv semyan morkovi stolovoi (Daucus carota L.), ukropa pakhuchego (Anethum graveolens L.) v usloviyakh Nechernozemnoi zony Rossii. Avtoreferat kandidatskoi dissrtatsii [The increase of seed viability in carrot (Daucus carota L.) and dill (Anethum graveolens L.) in the Russian Non-chernozem zone. PhD Thesis]. Moscow, 2011 (in Russ.).

25. Potekhin G.A. Otsenka $i$ otbor iskhodnogo materiala petrushki (Petroselinum crispum (Mill.) Nym.) dlya selektsii na produktivnost' $i$ kachestvo $i$ razrabotka elementov tekhnologii povysheniya posevnykh kachestv semyan. Avtoreferat kandidatskoi dissrtatsii [Evaluation and selection of parental parsley (Petroselinum crispum (Mill.) Nym.) plants for crop yield and quality breeding, and the methods to increase seed viability. PhD Thesis]. Moscow, 2011 (in Russ.).

26. Stats yuk N.V., Kuz netsova M.A., Fili p pov A.V., E 1 i s e e va L.G. Sakhar, 2014, 10: 38-40 (in Russ.).

27. Kuznetsova M.A. Obosnovanie primeneniya nekotorykh biologicheski aktivnykh preparatov $i$ sredstv dlya zashchity kartofelya ot fitoftoroza. Kandidatskaya dissertatsiya [Founded use of certain biologacals and agents to protect potatoes from late blight. PhD Thesis]. Moscow, 2000 (in Russ.).

28. Savitskaya N.G. Povyshenie tovarnogo kachestva, pishchevoi tsennosti $i$ sokhrannosti ovoshchnoi produktsii putem obrabotki ee nizkochastotnym elektricheskim polem. Kandidatskaya dissertatsiya [Increasing commercial quality, nutritional value and safety of vegetable production using lowfrequency electric field treating. PhD Thesis]. Moscow, 2001 (in Russ.).

29. Statsyuk N.V., Kuz netsova M.A., Rogozhin A.N., Filippov A.V. Biotika, 2015, 3(4): 10-12 (in Russ.).

30. S t a t s y u k N.V. Vestnik OrelGAU, 2015, 4(55): 93-98 (in Russ.).

31. Dos pekhov B.A. Metodika polevogo opyta s osnovami statisticheskoi obrabotki rezul'tatov issledovanii [Field trials with statistical analysis]. Moscow, 1985 (in Russ.).

32. Cramariuc R., Donescu V., Popa M., Cramariuc B. The biological effect of the electrical field treatment on the potato seed: agronomic evaluation. Journal of Electrostatics, 2005, 63: 837-846 (doi: 10.1016/j.elstat.2005.03.082).

33. Gu t M. Impact of alternating electric field on potato tuber growth and cropping. Inżynieria Rolnicza, 2007, 8(96): 73-79.

34. Marks N., S z e c y w k a P.S. Impact of variable magnetic field stimulation on growth of aboveground parts of potato plants. Int. Agrophys., 2010, 24: 165-170.

35. Sh mig e l' V.P., P ot a n i n a N.D. Kartofel' $i$ ovoshchi, 1977, 3: 14 (in Russ.).

36. G o r d e e v Yu.A. Metodologicheskie i agrobiologicheskie osnovy predposevnoi bioaktivatsii semyan sel'skokhozyaistvennykh kul'tur potokom nizkotemperaturnoi plazmy. Avtoreferat doktorskoi dissertatsii [Methodological and agrobiological bases of pre-sowing crop stimulation by lowtemperature plasma. DSci Thesis]. Smolensk, 2012 (in Russ.).

37. Tsugle nok G.I. Sistema issledovaniya elektrotekhnologicheskikh protsessov VCH i SVCH obrabotki semyan. Avtoreferat doktorskoi dissertatsii [The system to study processes of seed treatment with high frequency and microwave electormagmetic fields. DSci Thesis]. Krasnoyarsk, 2003 (in Russ.). 